\title{
Development of Knowledge Sharing Model using Decision Support System In Determine Feasible on the bob Training In Vocational School Using Vikor Method
}

\author{
Safrizal $^{1}$, Ambyar ${ }^{2}$, Unung Verawardina ${ }^{3}$ \\ ${ }^{1,2,3}$ Universitas Negeri Padang \\ ${ }^{1}$ Universitas Potensi Utama \\ ${ }^{1}$ rizalsyl75@gmail.com,2ambyar@ft.unp.ac.id, ${ }^{3}$ unungverawardina@gmail.com
}

\begin{abstract}
Decision support system (SPK) as a system that can process input data into one information that can be used as a more accurate decision support for the school in recommending students who meet the categories or requirements in following the Job Training. The system that was built carried out the process of determining decision support based on the Vise Kriterijumska Optimizajica I Kompromisno Resenje (VIKOR) method which is able to simplify complex problems in determining feasible to follow the On The Job Trainings based on criteria using formulas whose results are right on target.
\end{abstract}

Keywords: Decent Determination of PKL, Decision Support System, VIKOR

\section{Introduction}

Vocational High School (SMK) is a form of formal education unit that organizes vocational education at the secondary education level as a continuation of SMP / MTs or other equivalent forms. Vocational Schools aim to: (1) prepare students to be able to work, either independently or fill existing jobs in the business and industrial world as a middle-level workforce, in accordance with the fields and programs of interest they are interested in, (2) equip students to be able to choose a career, be tenacious and be persistent in competence and be able to develop professional attitudes in the areas of expertise that are of interest, and (3) equip students with Science and Technology (Science and Technology) to be able to develop themselves through higher education levels.

The reality that occurs is very different from what is expected in learning and school goals. Middle school championships (SMKs) are the highest contributor to open unemployment in Indonesia. This is contrary to the initial plan to make SMK graduates as graduates who can be directly absorbed by the business world. The Central Statistics Agency (BPS) noted, of the 7 million open unemployment as of August 2018, 11.24\% were vocational graduates. That percentage is higher than the open unemployment of 7.95\% high school graduates according to Articles in Kompas.com in 2019.

Data from the Central Statistics Agency in 2017 shows that the largest number of unemployed is dominated by vocational high school (SMK) graduates, amounting to 9.84 percent. President Joko Widodo instructed to revamp the vocational education system. In addition, the government must also reorient vocational education towards demand driven. Through Presidential Instruction (Inpres) No. 9 of 2016 stressed the need for SMK revitalization to improve the quality of human resources. The Presidential Instruction assigns the Ministry of Education and Culture to create a road map for SMK development, as well as perfecting and aligning the SMK curriculum with competencies according to graduate users (link and match). The Ministry of Education and Culture is also tasked with increasing the number and competency of vocational educators. By increasing cooperation with ministries / institutions, local governments, as well as 


\section{asinta ${ }^{(4)}$}

business and industry. Not only that, the Ministry of Educationanof culture also continues to improve access to graduate certification and vocationat accreditation establishment of a vocational school development working groụp tas also been out.

Of course there are many factors that influence vocational graduates to compete in the industrial world. In addition to improvements and improvements made through the curriculum, the need for the support of business actors or each company. Some obstacles that usually arise when aviation vocational high school students do street vendors are (1) Limitations of basic Aviation science. They cannot be asked to do anything, especially those directly related to aircraft, especially those that relate directly to Safety and also the Critical Area because they do not understand Basic Aircraft, including Standard Practice, Hardware Safety and Quality materials, etc. which are mandatory for activities on the plane. (2) Legality. In Aviation, there are often audits from local and foreign authorities. Authorities often see the capability possessed by each personnel. For example when there is a mechanic who does engineering work, it will be found because he is considered not legal to do the work because it is not legal to be an engineer. (3) Some of them still have student mentality so that when they are treated they are rarely among those who can be serious. That may be considered dangerous if they are given responsibility, especially those who have direct contact with the nurses.

Knowledge is a basic need that every human being must have in life. Humans are beings who think, act, and feel also act. Attitudes and actions are based on knowledge gained through feeling or thinking activities. The source of knowledge can come from anywhere. One such source is the world of education or school. Students are expected to have good knowledge, which will be applied in the real world or the world of work. Schools must be able to compete and innovate in responding to challenges from the outside world. The development of science requires students to keep abreast of the development of knowledge so that they can compete in the world of work [1]

Knowledge Sharing is a method of knowledge management that is used to provide opportunities for members or groups to share information with other parties, both information about skills or expertise. [2] Knowledge Sharing is recognized as a positive force for the survival of an organization [3], in transferring or disseminating knowledge among organizations, groups or individuals that will bring up new ideas [4]. With Knowledge Sharing as a bridge between industry knowledge and school knowledge, it becomes a unity that can be a collaboration of knowledge that supports the educational process in schools. The use of other Knowledge Sharing by users is limited to using existing online media, such as Facebook, Whatsapp, Instagram and many other online media. Users usually use these media in terms of sharing knowledge. Whether it's new knowledge, or old knowledge. Through this online media, users provide information both in the form of writing and pictures. Knowledge Sharing is not only used as information for teaching materials, but is able to provide information for teachers in providing information to students before they move towards practical fieldwork. Therefore, before students conduct fieldwork practices, it is expected that there is better communication between students and teachers and parties related to fieldwork practices.

The current condition is that students who will carry out On The Job Trainings are limited to a few general requirements. At present the requirements that must be carried out by students before pkl are students must be class XI and have passed all subjects with nothing remedial. Therefore, to help the problems that occur in Aviation Vocational Schools in determining the feasibility of street vendors for students, a method in the Decision Support System is needed, the Profile Matching method. Profile Matching is one of the methods in a Decision Support System. 


\section{Cisinta}

Profile matching is a decision making mechanism by assuning that there is an of ofeal level of predictor variables that must be met by the subjects stumeded, rather minimum level that must be met or passed [5].

\section{ResearchMethodology}

\subsection{On The Job Training}

Field Work Practice is one of the ways undertaken by the school in helping students get to know the world of work. PKL is one part of education that must be done by every student in the education process. On the Job Training or Field Work Practice is a form of application of the educational process that has been carried out, so that with this PKL it becomes a very positive value for students to be used as benchmarks or evaluations of educational success in the real world especially teachers and students [6][9][10]. Every school has its own rules in determining the street vendor process. In vocational school PKL travel schedule is done when students are in class XI (eleven) or second grade. While the period of street vendors is done for 6 months or 1 semester. The place to do street vendors is usually companies that must have cooperation with the school.

\subsection{Decision Support System}

The concept of SPK (Decision Support System) was first revealed in the early 1970s by Michael S. Scott Morton with the term Management Decision System. The term SPK refers to a system that utilizes computer support in the decision making process, the following is the opinion of experts about the understanding of SPK, including by Man and Watson namely SPK (Decision Support System) is a system that can help make decisions through the use of data and models the decision to solve problems that are semi-structured or unstructured [5] [7]. The concept of a Decision Support System will assist decision makers in determining an outcome from several alternative choices in order to provide a more accurate end result [8][17][18].

\subsection{VlseKriterijumska Optimizacija I Method Kompromisno Resenje (VIKOR)}

VlseKriterijumska Optimizacija I Kompromisno Resenje (VIKOR) is a multi-criteria optimization and compromise solution, which is one of the many MCDM techniques. VIKOR was first introduced by Serafim Opricovic in 1998 [12] [13] [14]. Then used in the problem of multi-criteria decision making in 200 VIKOR is based on the best solution obtained based on the closest ideal solution. Next do the ranking by comparing the distance to the ideal solution. The VIKOR method also uses linear normalization in order to get the best solution [15] [11].

The steps for calculation using the VIKOR method [11] [12] [16], as follows:

a) Normalize using the following formula:

$R_{i j}\left(\frac{x j+-x i j}{x j+-x i j-}\right)$

Where $\mathrm{Rij}$ and $\mathrm{Xij}(\mathrm{i}=1,2,3, \ldots, \mathrm{m}$ and $\mathrm{j}=1,2,3, \ldots, \mathrm{n})$ are elements of the decision making matrix (alternatives to the criteria $\mathrm{j}$ ) and $\mathrm{X}+\mathrm{j}$ are the best element of criteria $\mathrm{j}, \mathrm{Xj}$ is the best element of criteria $\mathrm{j}$.

b) Calculate $\mathrm{S}$ and $\mathrm{R}$ values using the formula:

$S_{i}=\sum_{j=1}^{n} W j\left(\frac{x j+-x i j}{x j+-x i j-}\right)$

Where $\mathrm{Wj}$ is the weight of each criterion $\mathrm{j}$. And...

$R_{i}=\operatorname{Maxj}\left\lfloor\left(\frac{x j+-x i j}{x j+-x i j-}\right)\right\rfloor$

Determine the index value

$Q_{i}=\left\lfloor\frac{\mathrm{Si}-\mathrm{S}+}{\mathrm{S}+\mathrm{S}-}\right\rfloor V+\left\lfloor\frac{R i-R+}{R+-R-}\right\rfloor(1-V)$

Where $\mathrm{S}-=\max \mathrm{Si}, \mathrm{S}+=\min \mathrm{Si}$ and $\mathrm{R}-=\max \mathrm{Ri}, \mathrm{R}+=\min \mathrm{Ri}$ and $\mathrm{v}=0.5$.

c) Grinding results are the results of sorting by $S, R, Q$. 


\section{Cisinta}

d) The best alternative ranking solution based on the minimun Q Q rating with the following conditions:

$\left.\mathrm{Q}\left(\mathrm{A}^{(2)}\right)-\mathrm{Q}^{((1)}\right) \geq \mathrm{DQ}$

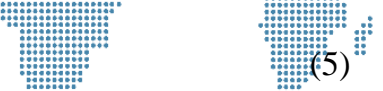

Where $\mathrm{A}(2)=$ alternative with second order in Q ranking and $\mathrm{A}$ " $(1)=$ alternative with the best sequence in $\mathrm{Q}$ ranking while $\mathrm{DQ}=1-(\mathrm{m}-1)$, where $\mathrm{m}$ is the alternative number. Alternative A (1) must be in the best rank on S and / or R

\section{Results and Discussion}

In this study the criteria used to determine the best PKL Eligibility are Administration, Academic, Non Academic. This research will discuss a support system that can help to determine the best Raskin recipients using the VIKOR method. The following is a list of alternatives and criteria for the selection of Raskin assistance, which are in Table 1 and Table 2.

\section{Table 1. Alternative Data}

\begin{tabular}{|l|l|}
\hline Alternative & Name \\
\hline A1 & Sahren \\
\hline A2 & Adinda \\
\hline A3 & Prasetyo \\
\hline A4 & Muamar \\
\hline A5 & Kayla \\
\hline
\end{tabular}

Table 2. Citeria Data

\begin{tabular}{|c|c|c|}
\hline Alternative & Name & Weight \\
\hline $\mathrm{C}_{1}$ & Administration & 0,3 \\
\hline $\mathrm{C}_{2}$ & Academic & 0,4 \\
\hline $\mathrm{C}_{3}$ & Non Academik & 0,2 \\
\hline $\mathrm{C}_{4}$ & Psychology & 0,1 \\
\hline \multicolumn{2}{|c|}{ Total Weight } & 1 \\
\hline
\end{tabular}

Furthermore, in tables 3 to 6 the weight of the criteria is Administration, Academic, Non Academic, Psychology Criteria.

Table 3. Administration

\begin{tabular}{|c|c|}
\hline Code & Administration \\
\hline Ad-01 & SPP money \\
\hline Ad-02 & Street vendors \\
\hline Ad-03 & Medical certificate \\
\hline
\end{tabular}

Table 4. Academic

\begin{tabular}{|c|c|}
\hline Code & Akademic \\
\hline Ak-01 & Basic Aviation \\
\hline Ak-02 & Basic Aircraft \\
\hline Ak-03 & Standard Practice \\
\hline Ak-04 & Hardware Safety and Quality \\
\hline
\end{tabular}

Table 5. Non Academic

\begin{tabular}{|c|c|}
\hline Kode & Non Akademik \\
\hline Na-01 & Pre OJT \\
\hline Na-02 & Pre OJT Result \\
\hline
\end{tabular}


Table 6. Psychology

\begin{tabular}{|l|l|}
\hline Code & Psychology \\
\hline Ps-01 & Teamwork \\
\hline Ps-02 & Behavior \\
\hline
\end{tabular}
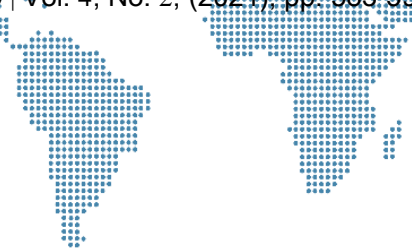

In table 7 , is a table that contains a rating of compatibility between alternatives and criteria.

Table 7. Match Ratings

\begin{tabular}{|c|l|c|c|c|c|c|c|c|c|c|c|c|}
\hline No & $\begin{array}{c}\text { Alternati } \\
\mathbf{f}\end{array}$ & Ad & Ad & Ad & Ak & Ak & Ak & Ak & Na & Na & Ps- & Ps- \\
& & - & - & - & - & - & - & - & - & 01 & 02 \\
\hline & & 01 & 02 & 03 & 01 & 02 & 03 & 04 & 01 & 02 & & \\
\hline 1 & Sahren & 5 & 3 & 3 & 3 & 4 & 3 & 3 & 3 & 4 & 2 & 2 \\
\hline 2 & Adinda & 2 & 3 & 4 & 5 & 4 & 3 & 5 & 5 & 4 & 5 & 5 \\
\hline 3 & Prasetyo & 4 & 5 & 5 & 3 & 4 & 5 & 5 & 4 & 3 & 2 & 4 \\
\hline 4 & Muamar & 3 & 2 & 4 & 3 & 3 & 5 & 5 & 5 & 4 & 5 & 4 \\
\hline 5 & Kayla & 3 & 2 & 4 & 5 & 2 & 5 & 3 & 5 & 3 & 5 & 4 \\
\hline
\end{tabular}

Step 1 Calculate Normalization

Table 8. Match Ratings

\begin{tabular}{|c|c|c|c|c|c|c|c|c|c|c|c|c|c|c|}
\hline \multirow[b]{2}{*}{ No } & \multirow[b]{2}{*}{$\begin{array}{c}\text { Alternati } \\
\mathbf{f}\end{array}$} & & \multicolumn{12}{|c|}{ Kriteria } \\
\hline & & $\begin{array}{c}\text { Ad- } \\
01\end{array}$ & $\begin{array}{c}\text { Ad } \\
- \\
02\end{array}$ & $\begin{array}{c}\text { Ad } \\
- \\
03\end{array}$ & $\begin{array}{c}\text { Ak } \\
- \\
01\end{array}$ & $\begin{array}{c}A k \\
- \\
02\end{array}$ & $\begin{array}{c}\text { Ak } \\
- \\
03\end{array}$ & $\begin{array}{l}\text { Ak- } \\
04\end{array}$ & $\begin{array}{c}\mathrm{Na} \\
- \\
01\end{array}$ & $\begin{array}{l}\mathrm{Na}- \\
02\end{array}$ & $\begin{array}{l}\text { Ps- } \\
01\end{array}$ & $\begin{array}{l}\text { Ps- } \\
02\end{array}$ & $\begin{array}{l}M \\
A \\
X\end{array}$ & $\begin{array}{l}\mathrm{M} \\
\mathrm{I} \\
\mathrm{N}\end{array}$ \\
\hline 1 & Sahren & 5 & 3 & 3 & 3 & 4 & 3 & 3 & 3 & 4 & 2 & 2 & 5 & 2 \\
\hline 2 & Adinda & 2 & 3 & 4 & 5 & 4 & 3 & 5 & 5 & 4 & 5 & 5 & 5 & 2 \\
\hline 3 & Prasetyo & 4 & 5 & 5 & 3 & 4 & 5 & 5 & 4 & 3 & 2 & 4 & 5 & 2 \\
\hline 4 & Muamar & 3 & 2 & 4 & 3 & 3 & 5 & 5 & 5 & 4 & 5 & 4 & 5 & 2 \\
\hline 5 & Kayla & 3 & 2 & 4 & 5 & 2 & 5 & 3 & 5 & 3 & 5 & 4 & 5 & 2 \\
\hline
\end{tabular}

Make a normalization matrix $(\mathrm{N})$ by determining the maximum and minimum values to get the ideal solution for each criterion.

$\mathrm{R}_{11} \frac{5-5}{5-4}=0 \quad \mathrm{R}_{12} \frac{5-5}{5-3}=0 \quad \mathrm{R}_{13} \frac{5-4}{5-3}=0.5 \quad \mathrm{R}_{21} \frac{5-5}{5-4}=0 \quad \mathrm{R}_{22} \frac{5-4}{5-3}=0.5 \quad \mathrm{R}_{23} \frac{5-5}{5-3}=0$ And so on so that the results obtained by normalizing the value of $\mathrm{R}$ based on the table above is seen in the table below:

Table 9. Normalization Results

\begin{tabular}{|c|c|c|c|c|c|c|c|c|c|c|}
\hline $\begin{array}{c}\text { Ad- } \\
01\end{array}$ & $\begin{array}{c}\text { Ad- } \\
02\end{array}$ & $\begin{array}{c}\text { Ad- } \\
03\end{array}$ & $\begin{array}{c}\text { Ak- } \\
01\end{array}$ & $\begin{array}{c}\text { Ak- } \\
02\end{array}$ & $\begin{array}{c}\text { Ak- } \\
04\end{array}$ & $\begin{array}{c}\text { Ak- } \\
04\end{array}$ & $\begin{array}{c}\mathrm{Na}- \\
01\end{array}$ & $\begin{array}{c}\mathrm{Na}- \\
02\end{array}$ & $\begin{array}{c}\text { Ps- } \\
01\end{array}$ & $\begin{array}{c}\text { Ps- } \\
02\end{array}$ \\
\hline 0 & 0.67 & 0.67 & 0.67 & 0.33 & 0.67 & 0.67 & 0.67 & 0.33 & 1 & 1 \\
\hline 1 & 0.67 & 0.33 & 0 & 0.33 & 0.67 & 0 & 0 & 0.33 & 0 & 0 \\
\hline 1 & 0.67 & 0.33 & 0 & 0.33 & 0.67 & 0 & 0 & 0.33 & 0 & 0 \\
\hline 0.33 & 0 & 0 & 0.67 & 0.33 & 0 & 0 & 0.33 & 0.67 & 1 & 0.33 \\
\hline 0.67 & 1.00 & 0.3 & 0.0 & 1.00 & 0.0 & 0.67 & 0.0 & 0.67 & 0.0 & 0.3 \\
\hline
\end{tabular}

Calculate the weight normalization matrix by multiplying criteria weights (W) with normalized data values 
Table 10. Weight Normalization Matrix With Giteria (W)

\begin{tabular}{|c|c|c|c|c|c|c|c|c|c|c|}
\hline $\begin{array}{c}\text { Ad- } \\
01\end{array}$ & $\begin{array}{c}\text { Ad- } \\
02\end{array}$ & $\begin{array}{c}\text { Ad- } \\
03\end{array}$ & $\begin{array}{c}\text { Ak- } \\
01\end{array}$ & $\begin{array}{c}\text { Ak- } \\
02\end{array}$ & $\begin{array}{c}\text { Ak- } \\
04\end{array}$ & $\begin{array}{l}\text { Ak- } \\
04\end{array}$ & $\begin{array}{c}\mathrm{Na}- \\
01\end{array}$ & \multicolumn{2}{|c|}{ 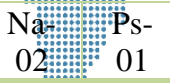 } & $\begin{array}{l}\text { Ps- } \\
02\end{array}$ \\
\hline 0 & 0.20 & 0.20 & 0.23 & 0.12 & 0.23 & 0.23 & 0.10 & 0.05 & 0.20 & 0.20 \\
\hline 0.30 & 0.20 & 0.10 & 0 & 0.12 & 0.23 & 0 & 0 & 0.05 & 0 & 0 \\
\hline 0.30 & 0.20 & 0.10 & 0 & 0.12 & 0.23 & 0 & 0 & 0.05 & 0 & 0 \\
\hline 0.1 & 0 & 0.0 & 0.23 & 0.12 & 0 & 0 & 0.05 & 0.10 & 0.20 & 0.07 \\
\hline 0.2 & 0.30 & 0.10 & 0 & 0.35 & 0 & 0.2 & 0 & 0.10 & 0 & 0.07 \\
\hline
\end{tabular}

Step 2: Calculate the values of $\mathrm{S}$ and $\mathrm{R}$

Table 11. S And R Values

\begin{tabular}{|r|r|r|r|r|r|r|r|r|r|r|r|r|}
\hline $\begin{array}{c}\text { Ad- } \\
01\end{array}$ & $\begin{array}{c}\text { Ad- } \\
02\end{array}$ & \multicolumn{1}{c|}{$\begin{array}{c}\text { Ad- } \\
03\end{array}$} & \multicolumn{1}{c|}{$\begin{array}{c}\text { Ak- } \\
01\end{array}$} & $\begin{array}{c}\text { Ak- } \\
02\end{array}$ & $\begin{array}{c}\text { Ak- } \\
03\end{array}$ & $\begin{array}{c}\text { Ak- } \\
04\end{array}$ & $\begin{array}{c}\text { Na- } \\
01\end{array}$ & $\begin{array}{c}\text { Na- } \\
02\end{array}$ & $\begin{array}{c}\text { Ps- } \\
01\end{array}$ & $\begin{array}{c}\text { Ps- } \\
02\end{array}$ & Si & Ri \\
\hline 0 & 0.20 & 0.20 & 0.23 & 0.12 & 0.23 & 0.23 & 0.10 & 0.05 & 0.20 & 0.20 & 1.77 & 0.23 \\
\hline 0.30 & 0.20 & 0.10 & 0 & 0.12 & 0.23 & 0 & 0 & 0.05 & 0 & 0 & 1.00 & 0.30 \\
\hline 0.30 & 0.20 & 0.10 & 0 & 0.12 & 0.23 & 0 & 0 & 0.05 & 0 & 0 & 1.00 & 0.30 \\
\hline 0.10 & 0 & 0 & 0.23 & 0.12 & 0 & 0 & 0.05 & 0.10 & 0.20 & 0.07 & 0.87 & 0.23 \\
\hline 0.20 & 0.30 & 0.10 & 0 & 0.35 & 0 & 0.23 & 0 & 0.10 & 0 & 0.07 & 1.35 & 0.35 \\
\hline
\end{tabular}

Step 3 : Ranking

Table 12. S And R Values

\begin{tabular}{|c|r|r|}
\hline Alternative & Si Values & Ri Values \\
\hline A1 & 1.77 & 0.23 \\
\hline A2 & 1.00 & 0.30 \\
\hline A3 & 1.00 & 0.30 \\
\hline A4 & 0.87 & 0.23 \\
\hline A5 & 1.35 & 0.35 \\
\hline S+ dan R+ & 1.77 & 0.35 \\
\hline S- dan R- & 0.87 & 0.23 \\
\hline
\end{tabular}

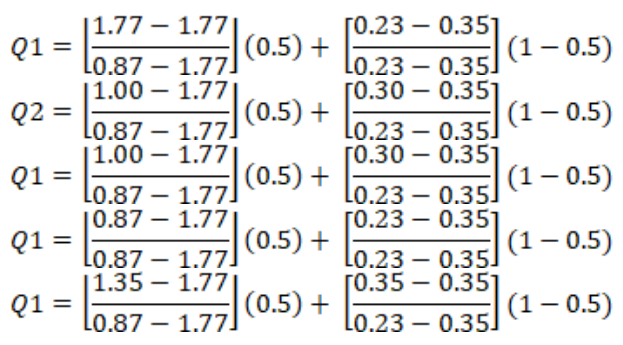

Table 13. Ranking

\begin{tabular}{|l|l|}
\hline Q1 & 0.50 \\
\hline Q2 & 0.64 \\
\hline Q3 & 0.64 \\
\hline Q4 & 1.00 \\
\hline Q5 & 0.23 \\
\hline
\end{tabular}

Step 4: The best alternative ranking solution based on the minimum $Q$ value.

Then the index value or which ranks 1 with the smallest result of 0.23 selected is Q5 or A5, namely Kayla. Thus the student named Kayla has the right to take On The Job Training first compared to other friends. 


\section{Conclusions}

Based on the discussion above, the researcher concludes that:

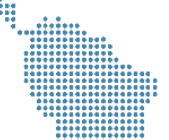

a) Analysis of the test using the VIKOR method shows that the U: UKOR methodecan be used to assist in making the selection process of PKL feasibility for Aviation Vocational students based on the appropriate weight and type preference requirements.

b) As for the assessment of student criteria based on three fields, namely Administrative, Academic, Non-Academic and Psychological, the VIKOR method is expected to be able to help in increasing transparency in the determination of eligibility for students as recommendations for improving the quality of education for students to be placed on the airline.

The selection results for selection of high school students using the VIKOR method, based on several criteria and interests of students 18 data from 30 tested samples, therefore, the accuracy value is as much as $60 \%$. While based on existing data as many as 25 of the 30 data samples tested, so the value of accuracy is as much as $83 \%$.

\section{References}

[1] Van Weert, T. J. (2006). Education of the twenty-first century: New professionalism in lifelong learning, knowledge development and knowledge sharing. Education and Information Technologies, 11(3-4), 217-237.

[2] Caruso, S. J. (2017). A foundation for understanding knowledge sharing: Organizational culture, informal workplace learning, performance support, and knowledge management. Contemporary Issues in Education Research, 10(1), 45.

[3] Wu, D. D., Wu, Y., \& Zhu, W. (2012). An integrated theoretical model for determinants of knowledge sharing behaviours. Kybernetes.

[4] Charband, Y., \& Navimipour, N. J. (2018). Knowledge sharing mechanisms in the education. Kybernetes.

[5] Kusrini, Konsep Dan Aplikasi Pemdukung Keputusan. Yogyakarta: Andi, 2007.

[6] Altonji, J. G., \& Spletzer, J. R. (1991). Worker characteristics, job characteristics, and the receipt of on-the-job training. ILR Review, 45(1), 58-79.

[7] Yuhandri, "Penerapan Decission Support System (Dss) Dalam Pemilihan Judul Pk1 Dan Skripsi Studi Kasus Universitas Putra Indonesia YPTK Padang," Maj. Ilm. UPIYPTK, vol. 1, no. 1, 2012.

[8] Safrizal, S. (2014). Rekam Jejak Dosen Sebagai Model Pengambilan Keputusan Dalam Pemilihan Dosen Berprestasi. Creative Information Technology Journal, 2(1), 65-76.

[9] Tanti, L., Rahmad, I. F., \& Thanri, Y. (2018, August). Monitoring and Evaluation of Flight Instructor Performance with PROMETHEE Method. In 2018 6th International Conference on Cyber and IT Service Management (CITSM) (pp. 1-6). IEEE.

[10] Safrizal, S. (2014). Rekam Jejak Dosen Sebagai Model Pengambilan Keputusan Dalam Pemilihan Dosen Berprestasi. Creative Information Technology Journal, 2(1), 65-76.

[11] B. J. Hutapea, M. A. Hasmi, and A. Karim, "Sistem Pendukung Keputusan Penentuan Jenis Kulit Terbaik Untuk Pembuatan Sepatu Dengan Menggunakan Metode VIKOR,” J. Ris. Komput., vol. 5, no. 1, pp. 6-12, 2018.

[12] M. Sianturi, S. Wulan, Suginam, Rohminatin, and Mesran, "Implementasi Metode VIKOR Untuk Menentukan Bahan Kulit Terbaik Dalam Pembuatan Ikat Pinggang," J. Ris. Komput., vol. 5, no. 1, pp. 56-60, 2018

[13] A. Mardani, E. Zavadskas, K. Govindan, A. Amat Senin, and A. Jusoh, "VIKOR Technique: A Systematic Review of the State of the Art Literature on Methodologies and Applications," Sustainability, vol. 8, no. 1, p. 37, Jan. 2016. 


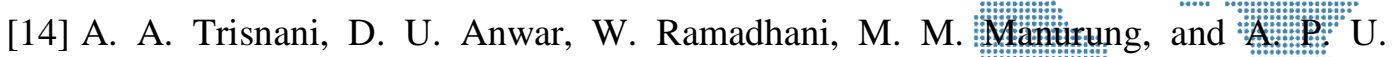

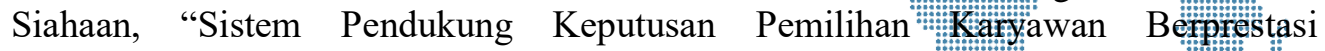
Menerapkan Metode Vise Kriterijumska Optimizajica I Kumpromisno 䇛esenje (VIKOR)," JURIKOM (Jurnal Ris. Komputer), vol. 5, no. 2, pp. 85-90, 2018.

[15] N. Sutrikanti, H. Situmorang, F. Fachrurrazi, H. Nurdiyânto, and M. Mesran, "Implementasi Pendukung Keputusan Dalam Pemilihan Calon Peserta Cerdas Cermat Tingkat SMA Menerapkan Metode VIKOR," JURIKOM (Jurnal Ris. Komputer), vol. 5, no. 2, pp. 109-113, Apr. 2018.

[16] D. Siregar et al., "Multi-Attribute Decision Making with VIKOR Method for Any Purpose Decision," J. Phys. Conf. Ser., vol. 1019, no. 1, 2018.

[17] Hardianto, N. Silitonga, B. S. Riza and E. V. H. S., "Application of Fuzzy Multi Criteria Decision Making for Determining Best Cooking Oil," 2018 6th International Conference on Cyber and IT Service Management (CITSM), Parapat, Indonesia, 2018, pp. 1-6, doi: 10.1109/CITSM.2018.8674300.

[18] F. Ikorasaki and M. B. Akbar, "Utilization ELECTRE Method with Decision Support System in Select Locations Warehouse Production," 2018 6th International Conference on Cyber and IT Service Management (CITSM), Parapat, Indonesia, 2018, pp. 1-4, doi: 10.1109/CITSM.2018.8674369 